\title{
Acute Oral Toxicity of the Crude Aqueous Extract of the Whole Plant of Euphorbia hirta L. (Family Euphorbiaceae)
}

\author{
Francis R. Capule
}

Department of Pharmacy, College of Pharmacy, University of the Philippines Manila

\begin{abstract}
Background. E. hirta or tawa-tawa is a small annual herb common to tropical countries. In the Philippines, the decoction of the whole plant is used for the treatment of dengue because of its apparent platelet increasing property. While efforts are ongoing to determine the role of $E$. hirta for dengue, this study focused on its safety.
\end{abstract}

Objective. This study determined the median lethal dose $\left(\mathrm{LD}_{50}\right)$, toxidromes and reversibility of toxic effects following the acute oral administration of the crude aqueous extract in SpragueDawley rats.

Methods. The Up-and-Down Procedure (Organization for Economic Cooperation and Development (OECD) Test Guideline 425) was conducted after the preliminary tests for the aqueous extract such as phytochemical and pesticide residue analyses and tests for aflatoxin and heavy metals.

Results. Phytochemical screening showed the presence of tannins, glycosides and alkaloids in the plant extract. The aqueous extract contained allowable aflatoxin levels. Organochlorines, organophosphates and heavy metals such as arsenic, cadmium, lead and mercury were not detected in the aqueous extract. The $\mathrm{LD}_{50}$ of the aqueous extract was greater than $5000 \mathrm{mg} / \mathrm{kg}$. However, it caused central nervous system (CNS) depression. A reversible loss of screen grip was observed at $2000 \mathrm{mg} / \mathrm{kg}$ and $5000 \mathrm{mg} / \mathrm{kg}$. A reversible analgesia was also seen at $5000 \mathrm{mg} / \mathrm{kg}$. The test animals did not experience significant body weight alterations. Gross necropsy revealed a hematoma on top of the skull and in the large intestine and a small, round protrusion in the stomach of test animals. Histopathological examination showed foci of perivascular hemorrhages and neuronal degeneration in the brain, multifocal submucosal hemorrhages in the large intestine and fragmented very dark staining nuclei and fibrin strands with red blood cells in the stomach of test animals.

Presented in the 13th Asian Conference on Clinical Pharmacy, September 13-15, 2013, Haiphong City, Vietnam.

Corresponding author: Francis R. Capule, MS, RPh

Department of Pharmacy

College of Pharmacy

University of the Philippines Manila

Taft Avenue, Manila 1000 Philippines

Telephone: +6325266115

Email: capulefrancis@gmail.com
Conclusion. While the acute oral $\mathrm{LD}_{50}$ of the aqueous extract is greater than $5000 \mathrm{mg} / \mathrm{kg}$, there is a need to pay attention to the toxidromes showing evidence of dose-dependent CNS depression. Histopathological examination showed multifocal submucosal hemorrhages and foci of perivascular hemorrhages and neuronal necrosis indicating an acute hemorrhagic enteritis and cerebral hemorrhage, respectively. These findings are crucial in the light of the anecdotal use of E. hirta for the treatment of dengue hemorrhagic fever.

Key Words: Euphorbia hirta, crude aqueous extract, acute oral toxicity, $L D_{50}$, toxidromes

\section{Introduction}

E. hirta, commonly known as tawa-tawa, is a small annual herb common to tropical countries like the Philippines. ${ }^{1-4}$ The decoction of the whole plant is used as a folkloric herbal treatment for dengue hemorrhagic fever in the country. ${ }^{5}$ A decoction from the whole plant is given to dengue patients, 1 to 1.5 glasses every hour for 24 hours. $^{6}$ The plant is believed to have platelet increasing property. Different animal studies showed consistent findings of a significant increase in platelet count. ${ }^{5,7-8}$ However, health authorities warn the general public in using this plant for dengue management because of insufficient efficacy and safety data available to support its clinical use and to validate the claims and testimonials from patients or healthcare professionals who were said to experience the clinical benefits of this plant.

Herbal medicines should be evaluated in terms of quality, efficacy and safety. While efforts are ongoing to determine the role of E. hirta for dengue, this study focused on its safety. In particular, the acute oral toxicity of the crude aqueous extract of the whole plant of E. hirta was determined in this study. The results of this preliminary study will then become a part of a database that is essential for the safety assessment of this plant.

\section{Materials and Methods}

\section{A. Collection and Preparation of Plant Material}

The fresh whole plant of E. hirta was obtained from the Dr. Jose Vera Santos Herbarium (Philippine University Herbarium), Institute of Biology, University of the Philippines (UP) Diliman. The voucher specimen (no. 6603) 
was deposited in this institution. The plant samples were collected from different sites in Quezon City within a period from March to May. After collection, the plant samples were compared with authenticated collections of the Institute and verified by Dr. James V. LaFrankie.

The whole plant samples were garbled, washed with tap water and air dried at the Student Research Laboratory, College of Pharmacy, UP Manila. The dried plant samples were cut into small pieces and then milled using Retsch Roto Beater Mill in the Solids Room, College of Pharmacy, UP Manila.

\section{B. Preparation of Extract}

Decoction was prepared by boiling $10 \mathrm{~g}$ of the plant material with $100 \mathrm{~mL}$ distilled water for 15 minutes in a stainless steel casserole. The crude aqueous extract was filtered through muslin cloth and concentrated. The concentrated aqueous extract was brown in color with a $\mathrm{pH}$ of 5.02. The concentrated extract was freeze dried using ChemLab SB4 lyophilizer at the Department of Orthopedics of Philippine General Hospital. A brown powder was produced. The percentage yield of the E. hirta freeze dried aqueous extract was $19.08 \%$. The freeze dried sample was stored in a refrigerator at 2 to $5^{\circ} \mathrm{C}$ and reconstituted 5 days after freeze drying. Reconstitution based on the test dose was done prior to the administration of the extract to test animals.

\section{Preliminary Tests}

A qualitative phytochemical screening of the aqueous extract was performed to determine the presence or absence of tannins, glycosides, reducing substances, alkaloids, plant acids, saponins, and flavonoids. The phytochemical test was conducted in the Plant Chemistry Laboratory, College of Pharmacy, UP Manila. The aqueous extract was sent to QualiBet Testing Services Corporation for the determination of aflatoxin by fluorometric method. The aqueous extract was also submitted to Sentro sa Pagsusuri, Pagsasanay at Pangangasiwang Pang-Agham at Teknolohiya Corporation for the pesticide residue analysis and test for heavy metals, arsenic, cadmium, lead and mercury. A quantitative analysis of the aqueous extract for several organochlorines and organophosphates was performed by gas chromatography. The aqueous extract was tested for the presence of lead and cadmium by inductively coupled plasma - atomic emission spectroscopy. The presence of arsenic and mercury in the aqueous extract was determined by atomic absorption spectrophotometry.

\section{Acute Oral Toxicity}

The Up-and-Down Procedure, which is an internationally accepted method adapted by the OECD Guideline for Testing of Chemicals, ${ }^{9}$ was used in the absence of established guidelines for the assessment of toxicity of herbal medicines. Like other acute toxicity tests, the Up-andDown Procedure can be used to reliably and reproducibly evaluate acute toxicity. But it uses fewer animals than the classical Acute Toxicity Test and the Fixed Dose Method. ${ }^{10}$ The procedure was slightly modified with the inclusion of negative control.

The toxicity study was conducted at the Animal Room of UP Manila-National Institutes of Health after the approval of the animal protocol by the UP Manila Institutional Animal Care and Use Committee and issuance of animal research permit by the Bureau of Animal Industry. The Animal Room is an Animal Biosafety Level (ABSL) 2 facility. The temperature in the Animal Room ranged from 19 to $25^{\circ} \mathrm{C}$. The relative humidity was maintained between 30 and $70 \%$. Artificial lighting was utilized with the sequence of 12 hours light and 12 hours dark.

Young healthy adults, 8-12 weeks old, female, nulliparous, non-pregnant, Sprague-Dawley rats were used. The animals were purchased from the Experimental Animal House Section of Food and Drug Administration. They were randomly selected, housed individually, and kept in their cages for at least 7 days prior to dosing to allow for acclimatization to the laboratory conditions. Sanitary cages and beddings were used. The animals were fed with standard pellet diet and purified water ad libitum.

Animals were fasted for 8 hours prior to dosing. Food but not water was withheld. Following the period of fasting, the animals were weighed before the administration of the aqueous extract. The determined fasted body weight was used for dose calculation. Doses were freshly prepared by dissolving appropriate amount of freeze dried sample in distilled water. The $\mathrm{pH}$ of the reconstituted solution was 5.19. The maximum dose volume for administration is 2 $\mathrm{mL} / 100 \mathrm{~g}$ body weight. The aqueous extract was administered in a single dose by gavage using a suitable intubation cannula. After the aqueous extract has been administered, food was withheld further for 4 hours. Distilled water was administered to negative control.

The Up-and-Down Procedure was divided into two parts: the limit test and the main test. In the limit test at 2000 $\mathrm{mg} / \mathrm{kg}$, the test dose was administered to one test animal (Test Animal (TA)1). Sequential dosing to four additional test animals (TA2, TA3, TA4 and TA5) was performed since the first test animal survived. Test animals were dosed at a minimum of 48-hour intervals. The LD50 was greater than $2000 \mathrm{mg} / \mathrm{kg}$ since all test animals survived. A limit dose at $5000 \mathrm{mg} / \mathrm{kg}$ was then performed.

In the limit test at $5000 \mathrm{mg} / \mathrm{kg}$, the test dose was administered to one test animal (TA6). Two additional test animals (TA7 and TA8) were dosed, one at a time, at a minimum of 48-hour intervals since the first test animal survived. The LD 50 was greater than $5000 \mathrm{mg} / \mathrm{kg}$ since all test animals survived. The main test was no longer performed because all test animals survived the limit test at $5000 \mathrm{mg} / \mathrm{kg}$. 
Animals were observed individually for a total of 14 days. The Irwin's Multidimensional Observation and Score Worksheet was utilized. Individual weights of animals were determined shortly before the extract was administered and weekly thereafter. At the end of the test surviving animals were weighed and then sacrificed by cervical dislocation after the administration of anesthesia. The animals were anesthetized using tiletamine-zolazepam $\mathrm{HCl}$ combination (Zoletil®) given intramuscularly prior to cervical dislocation. The dose was $30 \mathrm{mg} / \mathrm{kg}$. All animals were subjected to gross necropsy. All gross pathological changes were recorded for each animal. Organs with abnormalities were preserved using $10 \%$ formalin. The slide preparation was done at the Pathology Research Laboratory, College of Medicine, UP Manila. The histopathological examination was conducted in the Histopathology Room, College of Veterinary Medicine, UP Los Baños.

\section{Results}

\section{A. Preliminary Tests}

The results of phytochemical screening revealed the presence of tannins, glycosides and alkaloids in the aqueous extract. The aqueous extract contained 4 parts per billion (ppb) of total aflatoxin. The aqueous extract contained allowable level of aflatoxin. According to the European Commission, the acceptable limit for total aflatoxin is 4 $\mu \mathrm{g} / \mathrm{kg}$ or $\mathrm{ppb}$ for groundnuts, nut and dried fruits and processed products thereof, intended for direct human consumption or for use as an ingredient in food. ${ }^{11}$ Organochlorines, organophosphates and heavy metals such as arsenic, cadmium, lead and mercury were not detected in the aqueous extract (Tables 1 and 2). The method detection limit for organochlorines and organophosphates is 0.01 $\mu \mathrm{g} / \mathrm{mL}$ and $0.02 \mu \mathrm{g} / \mathrm{mL}$, respectively. $0.005 \mu \mathrm{g} / \mathrm{mL}$ is the method detection limit for arsenic, $0.05 \mu \mathrm{g} / \mathrm{mL}$ for cadmium, $0.10 \mu \mathrm{g} / \mathrm{mL}$ for lead and $0.20 \mu \mathrm{g} / \mathrm{mL}$ for mercury.

\section{B. Acute Oral Toxicity}

\section{Limit Test at $2000 \mathrm{mg} / \mathrm{kg}$}

The LD50 was greater than $2000 \mathrm{mg} / \mathrm{kg}$ because all test animals (TA1, TA2, TA3, TA4 and TA5) survived the limit test at $2000 \mathrm{mg} / \mathrm{kg}$ (Table 3). The limit test at $5000 \mathrm{mg} / \mathrm{kg}$ was conducted.

\section{Limit Test at $5000 \mathrm{mg} / \mathrm{kg}$}

The LD50 was greater than $5000 \mathrm{mg} / \mathrm{kg}$ because all test animals (TA6, TA7 and TA8) survived the limit test at 5000 $\mathrm{mg} / \mathrm{kg}$ (Table 3).

\section{Toxidromes}

TA1, TA3 and TA4 did not show any manifestations of toxicity in the limit test at $2000 \mathrm{mg} / \mathrm{kg}$. CNS depression was evident in TA2 and TA5. Specifically, a reversible loss of screen grip was observed. The rats fell off when the screen was inverted. No equivocal loss was seen after 8 days and 1 day from the onset of this effect in TA2 and TA5, respectively.

Table 1. Results of pesticide residue analysis

\begin{tabular}{|c|c|}
\hline Parameters & Result \\
\hline \multicolumn{2}{|l|}{ Organochlorines, $\mu \mathrm{g} / \mathrm{mL}$} \\
\hline Aldrin & ND \\
\hline Alpha-BHC & ND \\
\hline Beta-BHC & ND \\
\hline Delta-BHC & ND \\
\hline Dieldrin & ND \\
\hline Endosulfan I & ND \\
\hline Endosulfan II & ND \\
\hline Endosulfan sulfate & ND \\
\hline Endrin & ND \\
\hline Endrin aldehyde & ND \\
\hline Gamma-BHC & ND \\
\hline Heptachlor & ND \\
\hline Heptachlor epoxide & ND \\
\hline Methoxychlor & ND \\
\hline 4,4'-DDD & ND \\
\hline 4,4'-DDE & ND \\
\hline 4,4 -DDT & ND \\
\hline \multicolumn{2}{|l|}{ Organophosphates, $\mu \mathrm{g} / \mathrm{mL}$} \\
\hline O,O,O Triethylphosphorothiolate & ND \\
\hline Thionazin & ND \\
\hline Sulfotepp & ND \\
\hline Phorate & ND \\
\hline Dimethoate & ND \\
\hline Disulfoton & ND \\
\hline Methyl parathion & ND \\
\hline Parathion & ND \\
\hline Famphur & ND \\
\hline
\end{tabular}

Table 2. Results of test for heavy metals

\begin{tabular}{lc}
\hline \multicolumn{1}{c}{ Parameters } & Result \\
\hline Lead $(\mathrm{Pb}), \mu \mathrm{g} / \mathrm{mL}$ & $\mathrm{ND}$ \\
Cadmium $(\mathrm{Cd}), \mu \mathrm{g} / \mathrm{mL}$ & $\mathrm{ND}$ \\
Arsenic $(\mathrm{As}), \mu \mathrm{g} / \mathrm{mL}$ & $\mathrm{ND}$ \\
Mercury $(\mathrm{Hg}), \mu \mathrm{g} / \mathrm{mL}$ & $\mathrm{ND}$ \\
\hline Legend: & \\
ND $=$ none detected &
\end{tabular}

Table 3. Mortality of test animals in the Up-and-Down Procedure

\begin{tabular}{lcc}
\hline & $\begin{array}{c}\text { Limit Test at 2000 } \\
\mathbf{~ m g / k g}\end{array}$ & $\begin{array}{c}\text { Limit Test at 5000 } \\
\mathbf{~ m g / k g}\end{array}$ \\
\hline Number of Test Animals Used & 5 & 3 \\
Number of Deaths & 0 & 0 \\
Percentage (\%) of Mortality & 0 & 0 \\
\hline
\end{tabular}

Signs of CNS depression were also manifested by all test animals (TA6, TA7 and TA8) given $5000 \mathrm{mg} / \mathrm{kg}$ of the aqueous extract. These signs included analgesia and loss of screen grip. A reversible loss of sensation to pain was 
observed in TA8. No response to pain caused by pressing the toe of the hind foot of the rat using one's fingernail was recorded on days 4 and 5 . This effect was reversed on day 6 .

TA6, TA7 and TA8 showed a reversible loss of screen grip. No equivocal loss was observed day after the onset of this effect in TA6. A recurrence of loss of screen grip was seen in TA7 and TA8. The first onset of this effect in TA7 was on day 2 . This effect was reversed on day 5 , recurred on day 6 , and reversed again on day 7 . On the other hand, this effect occurred five times with one to three days interval in TA8.

No toxidromes were observed in the negative control.

\section{Body Weight Monitoring}

After 7 days, the body weights increased in all test animals of both the limit test at $2000 \mathrm{mg} / \mathrm{kg}$ and limit test at $5000 \mathrm{mg} / \mathrm{kg}$ except in TA3 and TA6 (Table 4 and Figure 1). The body weight of TA3 decreased from $171.3 \mathrm{~g}$ to $165.7 \mathrm{~g}$. A decrease in the body weight of $0.2 \mathrm{~g}$ was recorded for TA6.

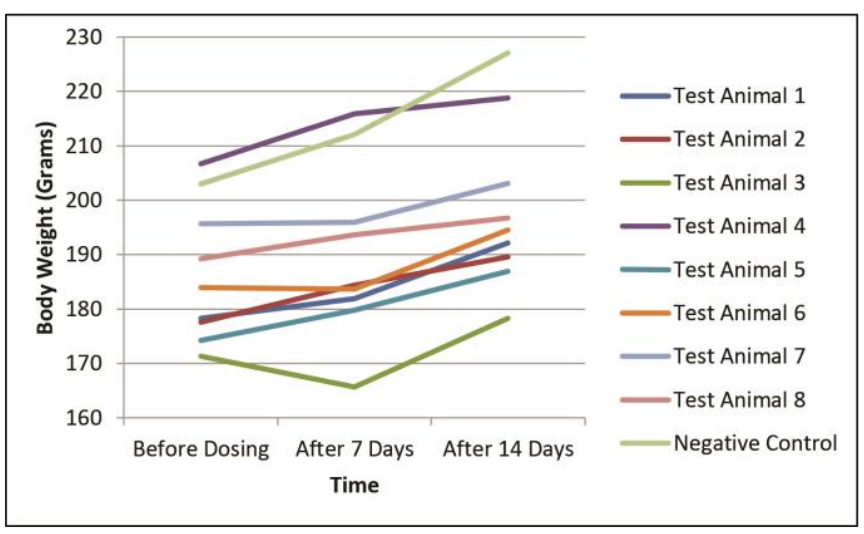

Figure 1. Body weight of test animals and negative control before and after dosing. After 7 days, the body weights increased in all test animals except in test animals 3 and 6. Test animals 3 and 6 had insignificant weight loss after the oral administration of $2000 \mathrm{mg} / \mathrm{kg}$ and $5000 \mathrm{mg} / \mathrm{kg}$ extract, respectively.

An increase in the body weights was documented for all test animals of both the limit test at $2000 \mathrm{mg} / \mathrm{kg}$ and limit test at $5000 \mathrm{mg} / \mathrm{kg}$ after 14 days.

\section{Gross Necropsy}

The gross necropsy of test animals 1, 2, 3, 4, and 6 revealed normal findings in the organs examined. A hematoma was found on top of the skull of TA5, TA7 and TA8. A hematoma was also found in the large intestine of TA5. A small, round protrusion was seen in the stomach of TA7 (Figures 2 and 3).

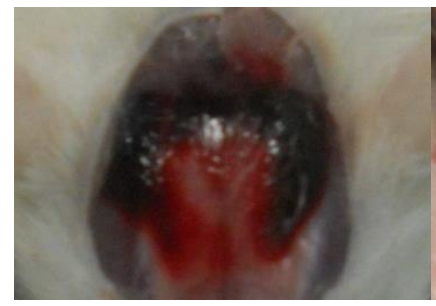

Test Animal 5

(Head)

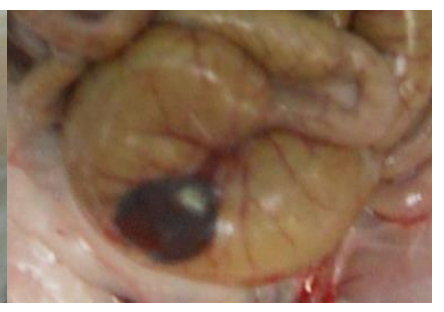

Test Animal 5

(Large Intestine)
Figure 2. Gross examination of organs collected from test animal in the limit test at $2000 \mathrm{mg} / \mathrm{kg}$

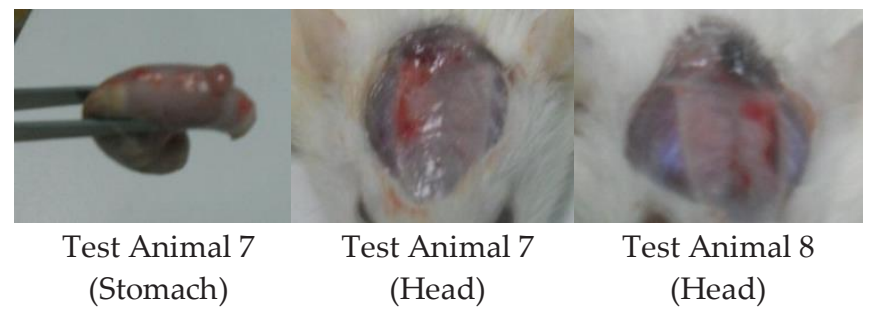

Figure 3. Gross examination of organs collected from test animals in the limit test at $5000 \mathrm{mg} / \mathrm{kg}$

\section{Histopathological Examination}

The results showed that the large intestine of TA5 manifested multifocal submucosal hemorrhages (Figure 4). In addition, foci of perivascular hemorrhages (Figure 5) and neuronal necrosis were seen in the cross section of brain tissue. The epithelia of mucosa of the stomach of TA7 showed fragmented very dark staining nuclei. Fibrin strands with red blood cells were also observed in slough off epithelia in lumen. The examined brain tissue section revealed dilated blood vessels with space around them

Table 4. Body weight of test animals in the Up-and-Down Procedure

\begin{tabular}{|c|c|c|c|c|c|c|c|c|c|}
\hline \multirow[b]{2}{*}{ Test Animal } & \multicolumn{5}{|c|}{ Limit Test at $2000 \mathrm{mg} / \mathrm{kg}$} & \multicolumn{3}{|c|}{ Limit Test at $5000 \mathrm{mg} / \mathrm{kg}$} & \multirow[b]{2}{*}{ NC } \\
\hline & TA1 & TA2 & TA3 & TA4 & TA5 & TA6 & TA7 & TA8 & \\
\hline Before Dosing & $178.3 \mathrm{~g}$ & $177.6 \mathrm{~g}$ & $171.3 \mathrm{~g}$ & $206.7 \mathrm{~g}$ & $174.2 \mathrm{~g}$ & $183.9 \mathrm{~g}$ & $195.7 \mathrm{~g}$ & $189.2 \mathrm{~g}$ & $203.0 \mathrm{~g}$ \\
\hline After 7 Days & $181.9 \mathrm{~g}$ & $184.4 \mathrm{~g}$ & $165.7 \mathrm{~g}$ & $215.9 \mathrm{~g}$ & $179.8 \mathrm{~g}$ & $183.7 \mathrm{~g}$ & $195.9 \mathrm{~g}$ & $193.6 \mathrm{~g}$ & $212.1 \mathrm{~g}$ \\
\hline After 14 Days & $192.1 \mathrm{~g}$ & $189.6 \mathrm{~g}$ & $178.3 \mathrm{~g}$ & $218.8 \mathrm{~g}$ & $186.9 \mathrm{~g}$ & $194.5 \mathrm{~g}$ & $203.1 \mathrm{~g}$ & $196.7 \mathrm{~g}$ & $227.1 \mathrm{~g}$ \\
\hline
\end{tabular}


(Figure 6). Foci of perivascular hemorrhages including vessels of meninges (Figure 7), foci of neuronal degeneration and some mononuclear cells in the walls of a few blood vessels were noted in the brain of TA8.

The results of the acute oral toxicity study are summarized in Table 5.

Table 5. Summary of the results of the Up-and-Down Procedure

\begin{tabular}{|c|c|}
\hline & $\begin{array}{c}\text { Limit Test at } 2000 \\
\mathrm{mg} / \mathrm{kg}\end{array}$ \\
\hline $\begin{array}{l}\text { Percentage (\%) of } \\
\text { Mortality }\end{array}$ & 0 \\
\hline \multirow[t]{2}{*}{ Toxidromes } & $\begin{array}{c}\text { Reversible loss of screen } \\
\text { grip } \\
\text { (TA2, TA5) }\end{array}$ \\
\hline & $\begin{array}{l}\text { No toxidromes } \\
\text { (TA1, TA3, TA4) }\end{array}$ \\
\hline \multicolumn{2}{|l|}{$\begin{array}{l}\text { Body Weight } \\
\text { Changes }\end{array}$} \\
\hline \multirow[t]{2}{*}{ After 7 days } & $\begin{array}{c}\text { Weight gain } \\
\text { (TA1, TA2, TA4, TA5) }\end{array}$ \\
\hline & $\begin{array}{l}\text { Weight loss } \\
\text { (TA3) }\end{array}$ \\
\hline After 14 days & $\begin{array}{c}\text { Weight gain } \\
\text { (all) }\end{array}$ \\
\hline \multirow[t]{3}{*}{ Gross Necropsy } & $\begin{array}{l}\text { Hematoma on top of the } \\
\text { skull } \\
\text { (TA5) }\end{array}$ \\
\hline & $\begin{array}{c}\text { Hematoma in large } \\
\text { intestine } \\
\text { (TA5) }\end{array}$ \\
\hline & $\begin{array}{l}\text { No gross pathological } \\
\text { findings } \\
\text { (TA1, TA2, TA3, TA4) }\end{array}$ \\
\hline $\begin{array}{l}\text { Histopathological } \\
\text { Examination }\end{array}$ & $\begin{array}{c}\text { Brain: foci of perivascular } \\
\text { hemorrhages } \\
\text { and neuronal necrosis }\end{array}$ \\
\hline
\end{tabular}

(TA5)

Large intestine: multifocal submucosal hemorrhages (TA5)

$\begin{gathered}\text { Limit Test at } 5000 \\ \mathrm{mg} / \mathrm{kg}\end{gathered}$
0

Reversible loss of screen grip

(TA6, TA7, TA8)

Reversible analgesia (TA8)

Weight gain
(TA7, TA8)

Weight loss

$$
\text { (TA6) }
$$

Weight gain (all)

Hematoma on top of the skull

(TA7, TA8)

Small, round protrusion in stomach

(TA7)

No gross pathological findings (TA6)

Brain: dilated blood vessels with space around them (TA7)

Brain: foci of perivascular

hemorrhages including vessels of meninges, foci of neuronal degeneration and some mononuclear cells in the walls of a few blood vessels (TA8)

Stomach: fragmented very dark staining nuclei

and fibrin strands with red blood cells (TA7)

\footnotetext{
Legend:

$T A=$ Test Animal
}

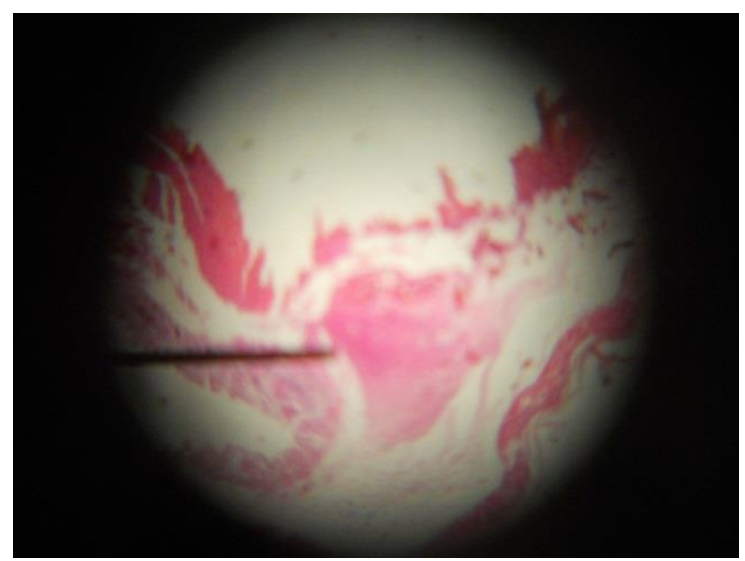

Figure 4. Histopathological examination of the large intestine from test animal 5 showing multifocal submucosal hemorrhages (Stain used: H \& E; Magnification: 10x)

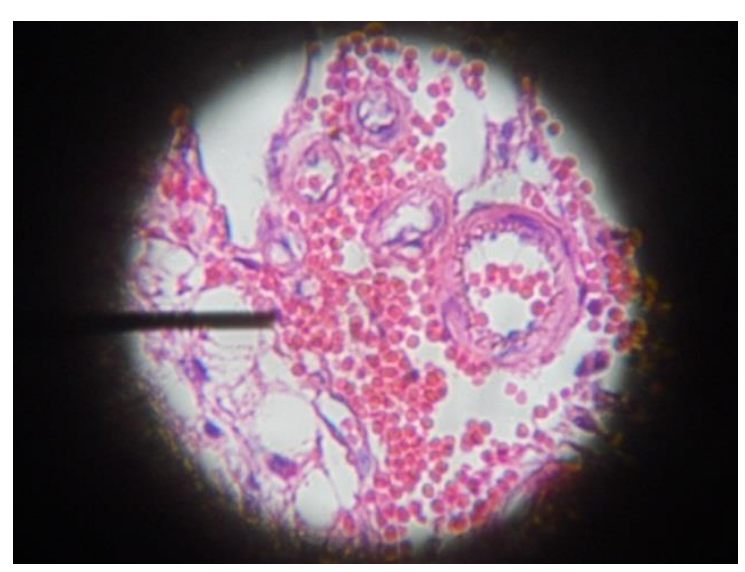

Figure 5. Histopathological examination of the brain from test animal 5 showing foci of perivascular hemorrhages (Stain used: H \& E; Magnification: 40x)

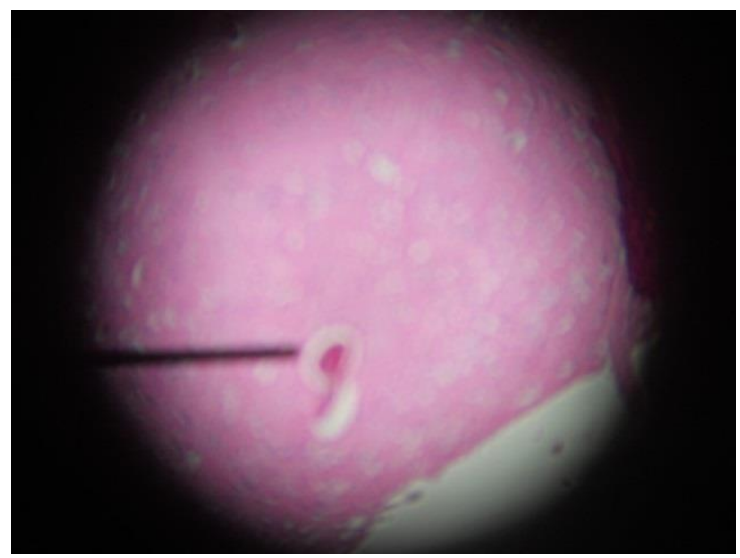

Figure 6. Histopathological examination of the brain from test animal 7 showing dilated blood vessels with space around them (Stain used: H \& E; Magnification: 10x) 


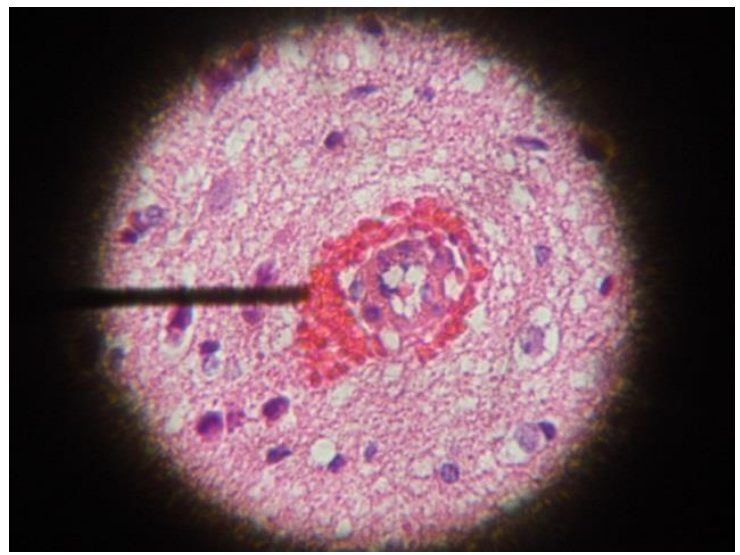

Figure 7. Histopathological examination of the brain from test animal 8 showing foci of perivascular hemorrhages including vessels of meninges (Stain used: $\mathrm{H}$ \& $\mathrm{E}$; Magnification: 40x)

\section{Discussion}

\section{A. Preliminary Tests}

The aqueous extract tested positive for the presence of tannins, glycosides and alkaloids. This concurred with previous studies done to determine the chemical constituents of the crude aqueous extract of the whole plant of E. hirta. According to these studies, the chemical constituents include tannins, saponins, volatile oils, alkaloids, steroids, flavonoids and glycosides. ${ }^{12-13}$ The aqueous extract contained allowable level of aflatoxin. Organochlorines, organophosphates and heavy metals such as arsenic, cadmium, lead and mercury were not detected in the aqueous extract. The absence of organochlorines, organophosphates and heavy metals in the aqueous extract indicates that the toxic effects observed in this study cannot be ascribed to these compounds.

\section{B. Acute Oral Toxicity}

Acute oral toxicity refers to those adverse effects occurring following oral administration of a single dose of a substance, or multiple doses given within 24 hours. $^{9}$ Lethality is only one of many reference points in defining acute toxicity. ${ }^{14}$ The LD 50 of the crude aqueous extract of the whole plant of E. hirta was greater than $5000 \mathrm{mg} / \mathrm{kg}$. Similar result was reported by Rajeh et al. ${ }^{15}$ They also found that the LD50 was higher than $5000 \mathrm{mg} / \mathrm{kg}$ following the acute oral administration of the crude methanolic extracts of E. hirta leaves in mice.

Seven to nine fresh whole plants of E. hirta are used in the community to prepare a one liter concoction for dengue fever. ${ }^{6}$ The approximate weight of seven to nine fresh whole plants ranges from $78.4 \mathrm{~g}$ to $100.8 \mathrm{~g}$. The crude aqueous extract was administered at a dose of $2000 \mathrm{mg} / \mathrm{kg}$ and 5000 $\mathrm{mg} / \mathrm{kg}$. These dose levels are equivalent to $730.5 \mathrm{~g}$ and
$1825.6 \mathrm{~g}$ of fresh whole plant for a $70 \mathrm{~kg}$ man, respectively. These amounts are much higher than the amount that is suggested in the preparation of concoction to treat dengue fever. This finding does not necessarily imply that the amount being used in the community is safe but rather, it indicates that the amount is lower than the doses at which acute toxic effects were observed. Further studies are therefore necessary to support this finding before the plant can be recommended for use in the treatment of dengue.

Although the LD50 can provide valuable information about the toxicity of the aqueous extract, the toxidromes and pathological findings are also vital or ever more critical than the $\mathrm{LD}_{50}$ in the evaluation of acute toxicity. ${ }^{14}$ The aqueous extract has CNS depressive effects. Specifically, at 2000 $\mathrm{mg} / \mathrm{kg}$, the aqueous extract caused a reversible loss of screen grip in TA2 and 5. All test animals (6, 7 and 8) given 5000 $\mathrm{mg} / \mathrm{kg}$ of the extract also demonstrated a reversible loss of screen grip. However, this CNS effect reappeared in TA7 and 8 . The grip strength test is a putative measure of muscular strength. Changes in grip strength have been interpreted as evidence of motor neurotoxicity. ${ }^{16}$ On the other hand, a reversible analgesia was observed in TA8. This finding is in accordance with the observations of Lanhers et al. ${ }^{17}$ They concluded that the lyophilized aqueous extract of the whole plant of E. hirta exhibited central analgesic properties, since it exerted a significant and dose-dependent protective effect on chemical at $20 \mathrm{mg} / \mathrm{kg}$ and thermic painful stimuli at $25 \mathrm{mg} / \mathrm{kg}$ and it was inhibited by naloxone suggesting a putative morphine-like activity profile for $E$. hirta.

Full recovery from the signs of CNS depression was complete except in test animal TA7 and 8. The reversibility of these signs is an indication that the extract was completely eliminated from the body of test animals. ${ }^{14}$ Another possible explanation is a decrease in receptor sensitivity of the possible receptor(s) of the extract. The recurrence of loss of screen grip seen in TA7 and 8 may indicate that the extract at a dose of $5000 \mathrm{mg} / \mathrm{kg}$ was not completely eliminated from the body and therefore, caused residual effects.

Body weight changes are also useful indices of toxicity. TA3 and 6 had weight loss 7 days after the oral administration of $2000 \mathrm{mg} / \mathrm{kg}$ and $5000 \mathrm{mg} / \mathrm{kg}$ extract, respectively. The alteration in body weights was not significant because it did not exceed $10 \%$ from the initial body weight. ${ }^{15}$

Pathological findings are likewise essential in the assessment of toxicological effects of $E$. hirta. Macroscopically, a hematoma was found on top of the skull of TA5, TA7 and TA8. A hematoma was also observed in the large intestine of TA5. A small, round protrusion was seen in the stomach of TA7. Histopathological examination showed that the large intestine of TA5 manifested multifocal submucosal hemorrhages indicating an acute hemorrhagic enteritis. In addition, foci of perivascular hemorrhages and 
neuronal necrosis indicative of acute cerebral hemorrhage were seen in the cross section of brain tissue. The epithelia of mucosa of the stomach of TA7 showed fragmented very dark staining nuclei. Fibrin strands with red blood cells were also observed in slough off epithelia in lumen. These findings are indications of acute necrosis of gastric mucosa. The examined brain tissue section revealed dilated blood vessels with space around them suggesting an acute cerebral congestion and perivascular edema. Manifestations of acute meningoencephalitis were noted in the brain of TA8. These manifestations included foci of perivascular hemorrhages including vessels of meninges, foci of neuronal degeneration and some mononuclear cells in the walls of a few blood vessels.

The abnormalities seen in the histopathological examination of brain tissues may be related to the neurologic signs observed in TA5, TA7 and TA8. However, the relationship of these findings needs to be established further.

Furthermore, it is of great importance to put emphasis on the fact that the aqueous extract caused hemorrhage. This finding has possible future implications in considering the aqueous extract of E. hirta for the management of dengue fever and its hemorrhagic form. The mechanisms by which the aqueous extract causes hemorrhage remain unclear. The administration of the extract may possibly result in internal hemorrhage due to coagulation deficiency. ${ }^{18}$

\section{Conclusion}

While the acute oral $\mathrm{LD}_{50}$ of the aqueous extract is greater than $5000 \mathrm{mg} / \mathrm{kg}$ there is a need to pay attention to the toxidromes showing evidence of dose-dependent CNS depression. Histopathological examination showed multifocal submucosal hemorrhages and foci of perivascular hemorrhages and neuronal necrosis indicating an acute hemorrhagic enteritis and cerebral hemorrhage, respectively. These findings are crucial in the light of the anecdotal use of E. hirta for the treatment of dengue hemorrhagic fever.

\section{Acknowledgment}

I would like to extend my deepest gratitude to the University of the Philippines Manila - National Institutes of Health for funding this study.

\section{References}

1. Basma AA, Zakaria Z, Latha LY, Sasidharan S. Antioxidant activity and phytochemical screening of the methanol extracts of Euphorbia hirta L. Asian Pac J Trop Med. 2011; 4(5):386-90.

2. Bhagwat GG, Mahadev CG, Sahebrao GD, Suresh PK, Govindrao YP, Onkar GR. Pharmacognostic study of plant Euphorbia hirta L. J Pharm Res. 2008; 1(1):39-43.

3. Ogbulie JN, Ogueke CC, Okoli IC, Anyanwu BN. Antibacterial activities and toxicological potentials of crude ethanolic extracts of Euphorbia hirta. AJB. 2007; 6(13):1544-1548.
4. Rajeh MA, Zuraini Z, Sasidharan S, Latha LY, Amutha S. Assessment of Euphorbia hirta L. leaf, flower, stem and root extracts for their antibacterial and antifungal activity and brine shrimp lethality. Molecules. 2010; 15(9):6008-18.

5. Lopez HS, Luna TAMS, Manalo RE, Natividad JAJ, Ngo CY, Apostol JG. A study on the platelet Increasing activity of the decoction and ethanolic extract of Euphorbia hirta L. (Euphorbiaceae) as a treatment for dengue hemorrhagic fever. Journal of Philippine Pharmacists Association. 2009; 2(1):16-23.

6. Gonzalez CEV. Climbing back to health [online]. 2011 [cited 2013 Apr]. Available from: http://opinion.inquirer.net/10803/what-we-can-do-tofight-dengue.

7. Cabangal EMW, Leynes EHG, Pacamparra SEC. Platelet increasing and hemostatic activity of tawa tawa capsules from Euphorbia hirta L. (Fam. Euphorbiaceae) [Undergraduate thesis]. Manila: University of the Philippines Manila, College of Pharmacy; 2008.

8. Dela Cruz CKF, Dela Vega CG, Diaz MSC, Enriquez PCI, Garcia RME. A Study on the Possible Mechanism of Action of the Platelet Increasing Property of the Decoction of Euphorbia hirta Linn [Undergraduate thesis]. Manila: University of Santo Tomas, Faculty of Pharmacy; 2010.

9. Organization for Economic Cooperation and Development, OECD Guideline for Testing of Chemicals: Acute Oral Toxicity - Up-and-Down Procedure [online]. 2001 [cited 2011 Aug]. Available from www.oecd.org/dataoecd/17/51/1948378.pdf.

10. Acute Toxicity Working Group, Interagency Coordinating Committee on the Validation of Alternative Methods (ICCVAM), Rationale for the Up-and-Down Procedure as Submitted to the OECD [online]. 1996 [cited 2011 Oct]. Available from http://ntp.niehs.nih.gov/iccvam/docs/ acutetox_docs/udpProc/udpfin01/append/AppJ2.pdf.

11. European Commission. Final Report of a Mission Carried Out in the United States of America from 11 September to 15 September 2006 in Order to Assess the Control Systems in Place to Control Aflatoxin Contamination in Almonds Intended for Export to the European Union. Brussels, Belgium: European Commission; 2006.

12. Hashemi SR, Zulkifli I, Hair Bejo M, Farida A, Somchit MN. Acute toxicity study and phytochemical screening of selected herbal aqueous extract in broiler chickens. Int J Pharma. 2008; 4(5):352-60.

13. Tona L, Kambu K, Ngimbi N, Cimanga K, Vlietinck AJ. Antiamoebic and phytochemical screening of some Congolese medicinal plants. J. Ethnopharmacol. 1998; 61(1):57-65.

14. Hayes AW. Principles and Methods of Toxicology, $3^{\text {rd }}$ ed. New York: Raven Press; 1994. pp. 582, 584-585.

15. Rajeh MA, Kwan YP, Zakaria Z, Latha LY, Jothy SL, Sasidharan S. Acute toxicity impacts of Euphorbia hirta L. extract on behavior, organs body weight index and histopathology of organs of the mice and Artemia salina. Pharmacognosy Res. 2012; 4(3):170-7.

16. Maurissen JP, Marable BR, Andrus AK, Stebbins KE. Factors affecting grip strength testing. Neurotoxicol Teratol. 2003; 25(5):543-53.

17. Lanhers MC, Fleurentin J, Dorfman P, Mortier F, Pelt JM. Analgesic, antipyretic and anti-inflammatory properties of Euphorbia hirta. Planta Med. 1991; 57(3):225-31.

18. Oyedemi SO, Bradley G, Afolayan AJ. Toxicological effects of the aqueous stem bark extract of Strychnos henningsii Gilg in Wilstar rats. J Nat Pharm. 2010; 1(1):33-9. 